\title{
Sustainable Entrepreneurial Intention: The Perceived Of Triple Bottom Line Among Female Students
}

\author{
Kartika Nuringsih, Nuryasman MN, Iwan Prasodjo, and Rita Amelinda \\ Faculty of Economics, Tarumanagara University, Jakarta \\ kartikan@fe.untar.ac.id
}

\begin{abstract}
The purpose of the study is to investigate the factors associated with the sustainable entrepreneurial intention on undergraduate students. In line with the sustainable development program, it observes the intention which is perceived by female students. Based on previous of studies, four variables are determined, consisting of role models, entrepreneurship education, entrepreneurial support, and green value. The female students of an economics faculty from one of the entrepreneurial universities in Jakarta were selected as the sample for the study. By using multiple regression, determinants of student intention was computed. Results are shown as follows: the perceived green value is able to predict the intention. Inversely, perceived role models, entrepreneurship education, and entrepreneurial support are insignificant. Understanding their perceptions within the concept of sustainable entrepreneurship is an important stage when designing the mechanism of triple bottom line implementation in the high education level, specifically in developing the entrepreneurial education.
\end{abstract}

Keywords: female students, intention, sustainable entrepreneurial, triple bottom line.

\section{INTRODUCTION}

The growth movement in the entrepreneurial sector has generated the risk probability in the environmental and social culture. An effort to balance between profit with environmental sustainability and social culture or local wisdom is needed as the foundation of entrepreneurship development. (Racelis, 2014) stated the main goal is creating the sustainable development through entrepreneurial activities. Entrepreneurial education has a substantial role to contribute to sustainable development improvement which actualizes through the sustainable-oriented learning system. (Patzelt and Shepherd, 2011) emphasized sustainable entrepreneurial activity is beneficial either to natural environment, communal environment, or economic development. Moreover, sustainable entrepreneurs anticipate the environmental shifting (Schaltegger and Wagner, 2011) and have roles in development of sustainable economy. Agree with Elkington's view (Elkington, 1999), sustainable entrepreneurship controls the triple bottom line (TBL), so the entrepreneurs manage the balance among profit, people, and the earth. Therefore, the educational institution should be responsible to develop the entrepreneurial characters of students. Sustainable knowledge or ethics will assist students in making a decision while considering the triple bottom line in each stage of entrepreneurial processes. 
One of the successful keys of the entrepreneurial process is creativity. In the flashback to the Schumpeter in 1934, indicated that the entrepreneur innovates through the process of creative destruction (Fong et al., 2014; Majid and Koe, 2012). Creative process consists of plenty of phenomena, such as climate change, population growth, human life expectancy or scarcity of the biodiversity. Generally, entrepreneurs are expected to contribute to the economic growth, innovation, and employment. It is needed the entrepreneur orientation in improving the entrepreneurial intention (Koe, 2016), specifically in sustainability issues (Kuckertz and Wagner, 2010). Finally, the aspirant entrepreneurs will evaluate the TBL's gap for each of the business opportunities. The sustainability of the economic system is related to the ecology aspect and sustainable development. Therefore, the entrepreneurship development ought to be relevant to the aspects. It should review how far the entrepreneurial education introduces the principles of sustainability to students. Thereby, they will desire to create the sustainable innovation and run the sustainability entrepreneurship in the future. Relevant with (Bhatnagar et al., 2013), (Braun, 2010), female students are rated potentially to be entrepreneurs who are inspiring in their surroundings.

Based on the previous studies e.g., (Kaijun and Sholihah, 2015), (Denanyoh et al., 2015), (Kartika and Ida, 2017), (Gerard and Saleh, 2011), (Turker and Selcuk, 2009), (Kennedy et al., 2003), (Kirkwood and Walton, 2010), (Kirkwood et al., 2014) are developed a model of entrepreneurial intention. Furthermore, the theory of planned behavior (TPB) is used to analyze the relation between entrepreneurship education, perceived role models, entrepreneurial support, and green value toward sustainable entrepreneurial intention. These determinants are inherent in a student's activity and psychology while learning entrepreneurship. It could be concluded that the research questions are as follows:

1. Is there a relation between each factor to sustainable entrepreneurial intention among female students?

2. How to encourage the implementation of the values' sustainable development in the entrepreneurial education system?

Concerning to the questions, the main objective of this study is to determine the dominant factor of the students' intention in the sustainable entrepreneurship. Therefore, it could design the mechanism of implementation of triple bottom line in the development of entrepreneurial education. Thereby, the novelty is to explore the entrepreneurial intention from sustainability framework, specifically in the entrepreneurial university students.

\section{THEORETICAL REVIEW}

Sustainable Development and Sustainable Entrepreneurship. According to the Organization for Economic Co-operation Development (OECD), sustainable development was defined as "The development that meets the need of the present without compromising the ability of the future generations to meet their own needs" (Strange and Bayley, 2008). The definition was cited from the report of World Commission on Environment Development (WCED) in 1987 (Majid et al., 2017), (Alhaddi, 2015). Corresponding to the model, the way to maintain future sustainability requires creativity to 
commit to nature conservation and social culture or local wisdom as an approach in the entrepreneurship development. Along with the environmental dynamics nowadays, entrepreneurship approach has also been progressing and shifting.

First, in 1934 Schumpeter stated about the innovative process of creative destruction (Fong et al., 2014; Majid and Koe, 2012; Schaltegger and Wagner, 2011). Entrepreneurs continuously innovate based on the environmental challenges either the change of climate, scarcity of biodiversity, or scarcity of water. Those degradations indeed become a trigger of entrepreneurs' creativity in the future. Second, in the 1970s, Harvard Business Review became a pioneer in the ecological movement which was represented by Quinn in 1971 and Elkington and Burke in 1989 argued that innovative business as the prospect and solution for the environment (Schaper, 2002). Third, in the 1990s, there were some research development models about eco-entrepreneurship, green entrepreneurship or environmental business. The entrepreneurial model is improved to the double bottom line, namely eco-entrepreneurship. Further studies were done by (Abina et al., 2015), (Kotchen, 2009), (Taylor and Walley, 2004), and others. Fourth, some of sustainable entrepreneurship studies have progressed, such as (Cohen and Win, 2007), (Schlange, 2009), (Patzelt and Shepherd, 2011), (Bell and Stellingwerf, 2012), (Majid and Koe, 2012), (Koe et al., 2014), (Majid et al., 2017), (Belz and Binder, 2017), and others. Along with the research progressing, sustainable entrepreneurship has become a synergy of aligning entrepreneurship program and sustainable development.

The consideration of sustainable development principles will cause the utilization of natural resources. They will also consider the balancing of the goals among profit, social, and ecology. The scarcity of natural resources could be handled by the concern on among sustainable. Agree with (Singh, 2009) initiated mind-sets shifting from the traditional model-based to the greening tomorrow market. It is similar to the green business concept. It means the implementation of environmentally sustainable concept triggers the corporate sustainability which becomes a competitive advantage for each corporate. In line with (Tilley and Young, 2009), (McEwen, 2013), sustainable entrepreneurship is defined as a business model which integrated the triple domains of the sustainable development. Concerning to the statement in the business approach, the red line of some definitions the sustainable entrepreneurship are described on Table 1.

Table 1. Definition of Sustainable Entrepreneurship

\begin{tabular}{ll}
\hline Sources & Definition \\
\hline $\begin{array}{l}\text { (Hockerts and } \\
\text { Wustenhagen, }\end{array}$ & $\begin{array}{l}\text { Sustainable entrepreneurship is the discovery and exploitation of } \\
\text { economic opportunities through the generation of market disequilibria that } \\
\text { initiate the transformation of a sector towards a sustainable environment } \\
\text { and society. }\end{array}$ \\
\hline $\begin{array}{l}\text { (Pacheco } \text { et al., } \\
2010)\end{array}$ & $\begin{array}{l}\text { Sustainable entrepreneurship as the discovery, creation, evaluation, and } \\
\text { exploitation of opportunities to create future goods and services that is } \\
\text { consistent with sustainable development goals. }\end{array}$ \\
\hline $\begin{array}{l}\text { (Patzeld and } \\
\text { Shepherd, 2010) }\end{array}$ & $\begin{array}{l}\text { Sustainable entrepreneurship is the discovery, creation, and exploitation of } \\
\text { opportunities to create future goods and services that sustain the natural } \\
\text { and/or communal environment and provide development gain for others. }\end{array}$ \\
\hline (Shepherd and & Sustainable entrepreneurship is focused on the preservation of nature, life \\
\hline
\end{tabular}

Jurnal Manajemen/Volume XXIII, No. 02, June 2019: 168-190 


\begin{tabular}{ll}
\hline Patzeld, 2011) & $\begin{array}{l}\text { support, and community in the pursuit of perceived opportunities to bring } \\
\text { into existence future products, processes, and services for gain, where gain } \\
\text { is broadly construed to include economic and non-economic gains to } \\
\text { individuals, the economy, and society. }\end{array}$ \\
\hline (Schaltegger and & $\begin{array}{l}\text { Sustainable entrepreneurship can thus be described as an innovative, } \\
\text { market-oriented and personality driven in creating value by an } \\
\text { environmentally or socially breakthrough in beneficial markets or } \\
\text { institutional innovations. }\end{array}$
\end{tabular}

Source: (Bell and Stellingwerf, 2012) (Binder and Belz, 2013)

Briefly, there are same relatively to define the sustainable entrepreneurship. Several statements on Table 1. conclude that sustainable entrepreneur activity is not only limited to the creation of product and service but also including the commitment and the environment equality. Therefore, business orientation is pioneered by two bottom line stages, progresses to triple bottom line. The progress is relevant to the convergent process model which was created by (Belz and Binder, 2017). It is relevant to the previous statement of (Choi and Gray, 2008) that sustainable entrepreneurship creates profitable enterprises and achieves certain environmental and social objectives. The process in pursuing ideas is often referred to as the double bottom-line or triple bottom-line. Thus, the integration of domains in the TBL creates the sustainability value for entrepreneurs and surroundings (Evans et al., 2016). By the reason, the business innovation must ensure the sustainability practices in seizing welfare without ignoring the need of the the future generations.

Entrepreneurial Intention and Theory of Planned Behavior. In general, by (Bird, 1988) intention was defined as the state of mind directing a person's attention and actions toward a specific object (goal) or a path in order to achieve something. According to (Ajzen, 1991) intention was defined as the indication of how hard people are willing to try or how much an effort they are planning to exert, in order to perform a behavior. Then, (Lee and Wong, 2004) stated entrepreneurial intention as an early step in a long process to start a new venture. It is as the state of mind leads to attract and influence to act in specific purpose or as the indication how strong the effort to achieve the objectives. Then, (Remeikiene et al., 2013) said the entrepreneurship intention serves as growing conscious state of mind that a person desires to start a new enterprise or to create new core value in existing organization. Thereby, intention is as the desire to create a new core value. Eventually, sustainable development will become a value or spirit for entrepreneurs. Along with the sustainability issues, intention is the long-term commitment in planning and introducing new venture. Therefore, this commitment could be realized by developing sustainability through triple bottom line. It is not a matter of profit, but entrepreneurs ought to be care with environmental and society problems.

According to Ajzen, intention will be part of behavior which is formed by an attitude toward the, social norm, and perceived al control (Majid et al., 2017), (Maresch et al., 2015), (Koe and Majid, 2014). (Nishimura and Tristan, 2011) stated "The theory of planned behavior is based on the assumption that human beings usually behave in a sensible manner, that they take account of available information, considering either the 
implicit or explicit implications of their actions". Furthermore, (Linan and Chen, 2006) identified three factors of intention, namely: (1) Attitude toward refers to the degree to which the individual holds a positive or negative personal valuation about being an entrepreneur. The determinants show that the individuals believe in assessing people either in a positive or negative way to entrepreneurship. (2) Social norm to measure the perceived social pressure to carry out or not to carry out that entrepreneurial. This determinant becomes a social trigger to do or not the entrepreneurial activity. (3) Perceived al control would be defined as the perception of the easiness or difficulty in the fulfilment of the behavior of interest (becoming an entrepreneur). The determinants show the level of belief either in easiness or difficulty while executing the entrepreneurship activity or the belief in controlling entrepreneurs' personality. Thus, the purpose of the using of TPB in the study is to capture the sensible manner of students interesting toward maintaining the sustainability in future.

Along with the improving the sustainable development in the entrepreneurial sector, the studies of entrepreneurial intention progress to the sustainability entrepreneurship. The broadening of intention is to overcome the environmental problems and social culture's gab. The previous studies were investigated by, e.g., (Linan 2008) in Spain, (Turker and Selcuk, 2009) in Turkey, (Ismail et al., 2009) in Malaysia, (Gerard and Saleh, 2011) in Tehran, (Astuti and Martdianty, 2012) in Indonesia, (Denanyoh et al., 2015) in Ghana, (Kaijun and Sholihah, 2015) in China and Indonesia, (Sahinidis et al., 2012) in Greek. Those studies have not been improved on sustainability issues. Therefore, the progressing model will investigate the intention of students to the sustainable entrepreneurship. The list of references in the sustainable entrepreneurial intention are detailed on table below.

Table 2. The Research of Sustainable Entrepreneurial Intention

\begin{tabular}{llll}
\hline Sources & Topic & Respondents & Results \\
\hline $\begin{array}{l}\text { (Abina } \text { et al., } \\
\text { 2015) }\end{array}$ & $\begin{array}{l}\text { The impact environment } \\
\text { concern, entrepreneurial } \\
\text { education, self-efficacy, } \\
\text { perceived barrier to entry, } \\
\text { perceived support, and } \\
\text { experience toward eco- } \\
\text { entrepreneurial intention. }\end{array}$ & $\begin{array}{l}\text { 250 students } \\
\text { at the university } \\
\text { in Ilorin and } \\
\text { Malete, Nigeria }\end{array}$ & $\begin{array}{l}\text { Environment concern, } \\
\text { perceived barrier to } \\
\text { entry, and perceived } \\
\text { support are significant } \\
\text { to eco-entrepreneurial } \\
\text { intention. }\end{array}$ \\
\hline $\begin{array}{lll}\text { (Kartika and } \\
\text { Ida, 2017) }\end{array}$ & $\begin{array}{l}\text { The impact education support, } \\
\text { structural support, formal } \\
\text { networking, informal }\end{array}$ & $\begin{array}{l}\text { 400 students at } \\
\text { one of } \\
\text { entrepreneurial } \\
\text { networking, green value, prior } \\
\text { university in }\end{array}$ & $\begin{array}{l}\text { Structural support, } \\
\text { formal networking, } \\
\text { informal networking, } \\
\text { green value, and prior } \\
\text { experience are } \\
\text { significant to eco- } \\
\text { eco-entrepreneurial intention. }\end{array}$ \\
& Jakarta & & $\begin{array}{l}\text { entrepreneurial } \\
\text { intention. }\end{array}$ \\
& $\begin{array}{l}\text { The relation of sustainability } \\
\text { attitude, social norm, } \\
\text { perceived desirability, and } \\
\text { perceived feasibility toward }\end{array}$ & 256 SMEs & $\begin{array}{l}\text { Four determinants are } \\
\text { ingnificant to propensity }\end{array}$ \\
& & & $\begin{array}{l}\text { for sustainable } \\
\text { entrepreneurship. }\end{array}$ \\
\hline Koe et al., & & &
\end{tabular}

Jurnal Manajemen/Volume XXIII, No. 02, June 2019: 168-190 


\begin{tabular}{llll}
\hline \multicolumn{3}{c}{$\begin{array}{l}\text { propensity for sustainable } \\
\text { entrepreneurship. }\end{array}$} & \\
\hline $\begin{array}{l}\text { (Koe and } \\
\text { Majid, 2014) }\end{array}$ & $\begin{array}{l}\text { The correlation of time } \\
\text { orientation, sustainable } \\
\text { orientation, social norm to } \\
\text { intention of sustainable } \\
\text { entrepreneurship. }\end{array}$ & $\begin{array}{l}\text { 404 SMEs } \\
\text { in Malaysia }\end{array}$ & $\begin{array}{l}\text { Determinants are } \\
\text { significant to propensity } \\
\text { for sustainable } \\
\text { entrepreneurship }\end{array}$ \\
\hline $\begin{array}{l}\text { (Koe } \text { et al., } \\
\text { 2015) }\end{array}$ & $\begin{array}{l}\text { The effect of sustainability } \\
\text { attitude, social norm, } \\
\text { perceived desirability, and } \\
\text { perceived feasibility toward } \\
\text { propensity for sustainable } \\
\text { entrepreneurship. }\end{array}$ & $\begin{array}{l}\text { 404 SMEs } \\
\text { in Malaysia. }\end{array}$ & $\begin{array}{l}\text { Four determinants are } \\
\text { significant to propensity } \\
\text { for sustainable } \\
\text { entrepreneurship. }\end{array}$ \\
\hline (Majid et al., & $\begin{array}{l}\text { The mediation effect among } \\
\text { sustainable value, sustainable } \\
\text { attitude, social norm, and } \\
\text { government legislation to the } \\
\text { intention toward sustainable } \\
\text { entrepreneurship. }\end{array}$ & in Malaysia & $\begin{array}{l}\text { Sustainable value, } \\
\text { sustainable attitude, } \\
\text { social norm and } \\
\text { governmental } \\
\text { legislation are } \\
\text { significant to intention. }\end{array}$ \\
& & & \\
\hline
\end{tabular}

Source: (Summarized by authors, 2018)

Table 2. shows the broadening conceptual of sustainable entrepreneurial intention. It illustrates the progressing of eco-entrepreneurial intention on students by (Abina et al., 2015), (Kartika and Ida, 2017) until the framework of sustainable entrepreneurial intention on business practices, e.g., (Koe et al., 2014), (Koe and Majid, 2014), (Koe et al., 2015), (Majid et al., 2017). Based on the descriptions are developed as a research model of intention on the entrepreneurial students. Consistently to the theory of planned behavior and previous researches, the hypothesis development will be discussed in the next section.

The Development of Hypothesis. Role models are considered as the factors in influencing the college students' intention. If the existence of role models could form the attitude and self-efficacy in person then it will form the interest to become a follower to its' role model in attitude context (Krueger et al., 2000). From the view of social learning theory by Bandura, the existence of role model consists of three benefits such as: provide learning, motivation, and inspiration and help individuals define their self-concept (Karimi et al., 2014). According to (Quimby and DeSantis, 2006), (Karimi et al., 2014), women indeed need more role models than men in choosing and referencing career. Formerly, (Kennedy et al., 2003), in executing a business, college students need a role model from parents, friends, experts, public figures, or lecturers. A role model acts as the inspiration of entrepreneurs. Therefore, it could be a consideration to examine the entrepreneurial intention. The belief in mentoring impacts to the attitude towards sustainability in themselves. Reciprocally, it will trigger business model attractiveness in sustainable development-oriented. According to the mechanism, the first hypothesis (H1) is: Perceived role models relate to the sustainable entrepreneurial intention. 
In ordinary entrepreneurship approach, studies of (Maresch et al., 2015), (Denanyoh, Adjei, and Nyemekye, 2015), found that entrepreneurship education affect to the intention positively. Entrepreneurship education is one of the accesses to entrepreneurial skill and knowledge. Entrepreneurship is taught to college students with the purpose of triggering the entrepreneurship intention through educational support. (Gerard and Saleh, 2011) identified this relation in Teheran, while (Turker and Selcuk, 2009) had a similar conclusion in Turkey. (Ismail, Khalid, and Othman, 2009), identified entrepreneurship course is significantly related to college students' intention in Malaysia. (Kaijun and Sholihah, 2015) found the impact of entrepreneurial education on entrepreneurial intention in China's college students, specifically on the perceived behavour control. Otherwise, it did not occur in Indonesia. In the eco-entrepreneurship view (Abina et al., 2015), (Kartika and Ida, 2017), indicated an insignificant relation between entrepreneurial education and eco-entrepreneurial intention. (McEwen, 2013) stated the entrepreneurship education not only attracts interest but also introduces college students to sustainable entrepreneurship as solution for the environmental changes. Education system or entrepreneurship learning will affect the perceived entrepreneurship education. Meanwhile, the perception form an attitude on sustainability, thinking on sustainability, and developing self-efficacy. Therefore, students are interested to consider the TBL as the spirit of executing business. Relevant to the mechanism, second hypothesis (H2) is: Entrepreneurship education relates to the sustainable entrepreneurial intention.

Previous studies such as (Gerard and Saleh, 2011), (Turker and Selcuk, 2009), and (Ismail, Khalid, and Othman, 2009) identified the relation between entrepreneurial support and intention. (Gerard and Saleh, 2011) used informal networking as the intention predictor. (Turker and Selcuk, 2009), (Denanyoh et al., 2015) stated that relational or structural support serves as a determinant of intention. Studies of (Kartika and Ida, 2017), (Abina et al., 2015), found a significant impact of perceived support on ecoentrepreneurial intention. Therefore, greater trust in cooperation will attract more interest in starting and developing a new venture. Based on prior studies, the perception of support and network in eco-friendly business will trigger students' intention on the sustainable entrepreneurship. Perceived entrepreneurial support is similar to social norm in planned behaviour theory. Basically, social norm is needed by students to build a business, inversely, those who have an internal locus of control tend to strongly neglect the opinions and do not have the concern about social norm. Especially to build business with local wisdom traditions, the belief on environmental and sustainability support will affect the attitude or personal valuation on sustainability, form social pressure on sustainability and self-efficacy. Therefore, students are interested to consider the TBL as the spirit to execute business. Relevant to the mechanism, the third hypothesis (H3) is: Perceived entrepreneurial support relates to the sustainable entrepreneurial intention.

Lastly, perceived green value determines the sustainable entrepreneurial intention. According to (Ng and Burke, 2010), social value was one of predictor student sustainable business attitudes in western United State. In accordance with Robin and Judge, value is the basic conviction of specific mode. While the meaning of green is to apply environment value to the benefit of the people and the earth. Based on (Kirkwood and Walton, 2010), (Kirkwood, Dwyer, and Walton, 2014), one of the motivations in eco-entrepreneur is caused by ethics or green value. While women are assumed to be more potential to 
succeed in their eco-entrepreneurship (Bhatnagar et al., 2013). Based on logics, students who tend to have green value have more interest in relevant business on sustainable development. Based on the view of psychology aspect, value refers to attitude, motivation, perception, and behaviour. In the double bottom line's concept, (Abina et al., 2015), (Kartika and Ida, 2017) concluded that perceived environment concern impacts on ecoentrepreneurial intention. Referring to (Kirkwood and Walton, 2010), (Abina et al., 2015), (Kartika and Ida, 2017), there is a relation between perceived green values and sustainable entrepreneurial intention. Values or ethics in the eco-friendly environment has a positive impact on attitude, motivation, perception, and entrepreneurial behaviour. Through motivation, it will impact attitude on sustainability, social pressure on sustainability and controlling behaviour to attract interest in sustainable entrepreneurship. Relevant to the mechanism, the fourth hypothesis $(\mathbf{H 4})$ is: Perceived green value relates to the sustainable entrepreneurial intention.

\section{METHODOLOGY}

The population are the female students of the Faculty of Economics in Tarumanagara University. The respondents consist of 300 female students in the Management Program which passes the basic of entrepreneurship class. This research used stratified random sampling as its sample selection method from the year of 2013-2015. These three years sampling comprised of an active college students who have sufficient entrepreneurship conceptual knowledge. The total sample of this research consists of 100 students each year which means a total of 300 students as the sample. The process of collecting data was done from October to December 2016. Female students in the selected sample agree with (Bhatnagar et al., 2013) who stated that females tend to have high motivation in executing eco-friendly business, and had stronger environment attitude (Braun, 2010). According to (Harris and Gibson, 2008), the business management program's students tend to have stronger entrepreneurial attitudes than those of the nonbusiness management. (Astuti and Martdianty, 2012) concluded that the TPB forms less entrepreneurial intention of non-business management students. Relevant to the previous studies who set the model of sustainable entrepreneurial intention for female students in the entrepreneurial university.

The sustainable entrepreneurial intention (SEI) is measured by the entrepreneurial intention questionnaire which is adopted from (Linan and Chen, 2006), (Koe and Majid, 2014). It consists of five indicators as follows: (1) I am ready to do anything to be an entrepreneur. (2) My professional goal is to be an entrepreneur. (3) I will make every effort to start and run my own firm. (4) I am determined to create a firm in the future. (5) I have got the firm intention to start a firm someday. The indicator of perceived role models (PRM) consists of three items which are adopted from (Kennedy et al., 2003). Perceived entrepreneurial support (PES) consists of three items as referred by (Linan and Chen, 2006). Entrepreneurship education (EDU) consists of three items as referred by (Kaijun and Sholihah, 2015) and (Gelard and Saleh, 2011). Finally, Perceived green value (PGV) consists of three items which are arranged by (Kirkwood and Walton, 2010). The items are presented to be a questionnaire with a scale of 1 (not strongly agree) to 4 (strongly agree).

Jurnal Manajemen/Volume XXIII, No. 02, June 2019: 168-190 
The accuracy of instruments refers to the value of cross loading, Cronbach's Alpha and composite reliability (Zikmund and Babin, 2010). The minimum criteria value of composite reliability is 0.60 for exploratory research (Hock and Ringle, 2006) while 0.70 for confirmatory research (Henseler et al., 2012). The Smart PLS program is used to analyze the relation between variables and instrument feasibility.

\section{RESULT AND DISCUSSION}

The Result of Statistical Tests. The profile of respondents comprises of (1) Female students from 24 cities in Indonesia with 195 from Jakarta, while the others from various cities such as Medan, Riau, Jambi, Belitung, Pontianak, Palembang, Bali, Banten, Bagansiapiapi, Manado, Jayapura, Padang, Sibolga, and others. (2) Approximately $84 \%$ of respondents do not have a business, while $9 \%$ of them have started a business, and the remaining others are executing the family business. Even though the respondents do not have enough courage in starting a business, most of them are interested in the triple bottom line implementation in entrepreneurship. That attractiveness could be led by intuition to introduce the sustainable entrepreneurship. (3) Most types of business are online shop $19 \%$, culinary $17 \%$, food and retail $13 \%$, and beauty salon $4 \%$. The other types of business are bakery, barber shop, beverage, catering, education, florist, and clothing. These businesses are identical to passion, talent, or trend. These kinds of business could be developed to prepare a business plan for the entrepreneur week event. As entrepreneurial university, the institution provides a variety of programs to suport students entrepreneurship skill such as: regularly organizing annual conference, entrepreneur week, business case competition, new venture exhibition, and others.

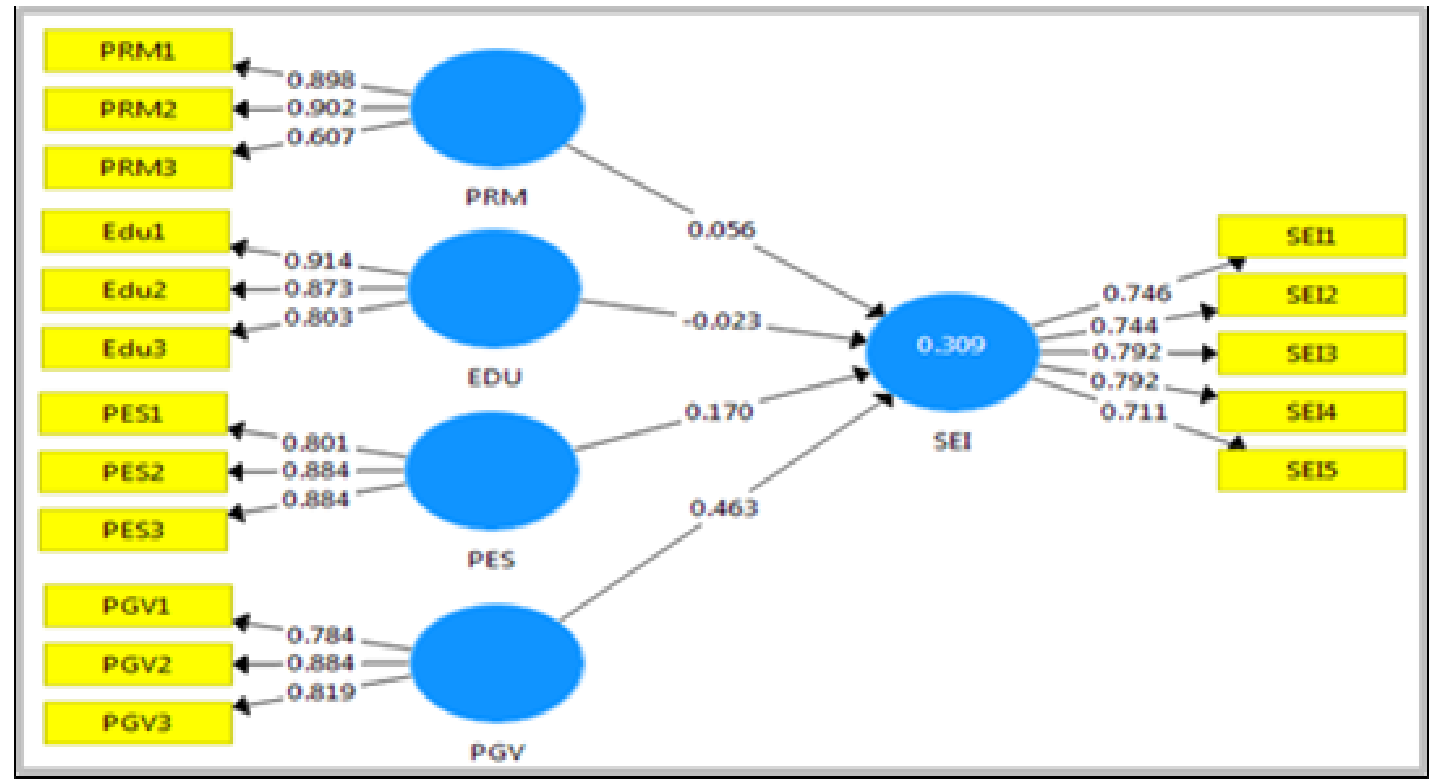

Figure 1. The Result of Outer Model SEI

Source: (the output of Smart PLS, 2018) 
Figure 1. indicates that the majority of the value of discriminant validity are above 0.70 . The strongest validity among sustainable entrepreneurial intention (SEI) indicators is SEI4 and SEI3 with a value of 0.792 and the minimum value is 0.711 on SEI5. The most valid one in role model indicator is PRM2 (0.892), while PRM3 has the lowest validity of 0.607. The strongest validity in entrepreneurship education (EDU) indicator is EDU1 (0.914), while the lowest is EDU3 (0.803). The strongest validity in perceived entrepreneurial support (PES) indicator is PES2 and PES3 with a value of 0.884, while the minimum one is 0.801 . The strongest validity in perceived green value (PGV) indicator is PGV2 (0.884), while the minimum one is PGV1 (0.784). The result shows that all of the indicators are valid to measure the five contracts. The value of Cronbach's Alpha is above 0.70: SEI (0.814), PRM (0.736), EDU (0.835), PES (0.821), and PGV (0.774). While for the reliability testing, the result shows the composite reliability value on SEI (0.871), PRM (0.852), EDU (0.899), PES (0.892), and PGV (0.869). In line with the overall testing, the indicators are stated as valid and reliable to measure contract. The value of NFI is 0.744 . It indicates that the data used in this research represent close to the fact.

Furthermore, the result of the testing identifies the value of $\mathrm{R}^{2}$ is 0.309 which indicates that the four determinants could contribute to explain sustainable entrepreneurial intention as much as $30.90 \%$, while $69.10 \%$ is influenced by other factors. To trigger more interest in sustainable entrepreneurship, it needs to include other variables. The greatest coefficient is perceived green value which influences positively as much as 0.463 . While perceived role models and entrepreneurial support influence insignificantly to the sustainable entrepreneurial intention. Entrepreneurship education influences insignificantly negative to SEI. It means the education orientation tends to trigger entrepreneurship in general. It has not inversely led to sustainable entrepreneurship.

Table 3. Correlation Matrix

\begin{tabular}{lccccc}
\hline Variable & SEI & PRM & EDU & PES & PGV \\
\hline SEI & 1.000 & & & & \\
\hline PRM & 0.233 & 1.000 & & & \\
\hline EDU & 0.114 & 0.236 & 1.000 & & \\
\hline PES & 0.323 & 0.337 & 0.260 & 1.000 & \\
\hline PGV & 0.526 & 0.271 & 0.174 & 0.304 & 1.000 \\
\hline \multicolumn{5}{c}{ Source: (the output of Smart PLS, 2018) }
\end{tabular}

Table 3. indicates that the correlation value between each independent variable is relatively low, so that it can be concluded that it does not contain multicollinearity in the model. One of the greatest correlation value is 0.526 between PGV and SEI, while the path value is 0.463 (see Figure 1). Then, the contribution of PGV is $0.244(0.526 \times 0.463)$ to SEI. It means if PGV increases one percent, it will make sustainable entrepreneurship intention increases 0.244. When it is compared with the correlation between PES and SEI, the contribution of PES is $0.055(0.323 \times 0.170)$ to the intention. It indicates the smaller value of perceived entrepreneurial support than perceived of green value to the intention of sustainable entrepreneurship. Therefore, the perceived of green value as the greatest 
contribution to the value of $\mathrm{R}$ square. The same computation is used to calculate the values of other coefficients of the intention determinants.

Figure 2 shows the greatest value of the t-test is 3.400 on the path between PGV to the intention. It could be concluded that the fourth hypothesis (H4) is accepted, while $\mathrm{H} 1$ to $\mathrm{H} 3$ are insignificant to the intention. The influence of perceived green value significantly attracts the interest of female students. The factor of interest is dominated by the female students' psychology. The green value is influenced by belief, family or community surroundings who concern about sustainable development. In line with the theory of planned behaviour, value or ethics will have impact on attitude, motivation, perception, and entrepreneurial behaviour. Through motivation, it will improve the attitude toward sustainability, pressure on social sustainability, and control the behaviour to attract students to sustainable entrepreneurship. The perception of green value is the basic for synergizing the entrepreneurial education system appropriate with environmental development.

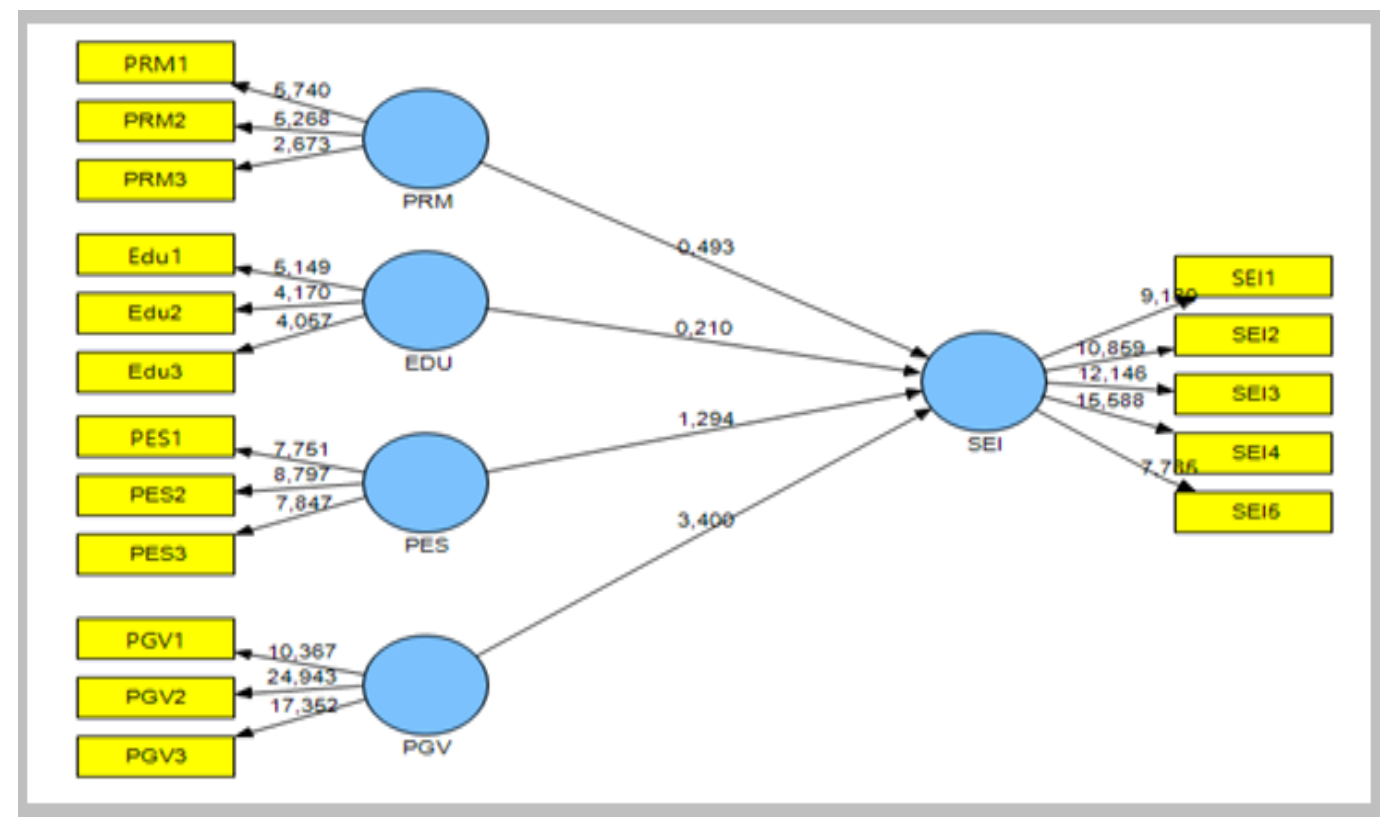

Figure 2. The Result of the t-Test in SEI Model

(Source: the output of Smart PLS, 2018)

Concerning to Figure 2, other determinants are not significant to the sustainable entrepreneurial intention. In other word, the perceived of role models, education support, and entrepreneurial support haven't effected significantly to the students intention. It means the majority of entrepreneurial students do not meet the insight from the programs. In fostering the behaviour, institution ought to collaborate with stakeholders and invites famous people, professional speakers or environmental experts which commit to the sustainability issues in Indonesia. Through the mechanism, the institution will create the entrepreneurial ecosystem for students, specifically in creating the sustainability circles. 
Table 4. illustrates the descriptive statistics of perceived green value indicators. Both support the finding that perceived green value has significantly positive influence on sustainable entrepreneurial intention. The perception of green value is represented by lifestyle, spirit to educate society or community, and the willingness to cooperate with the government or community to socialize the sustainability program. Those responses represent the mindset of double bottom line in the business implementation. In other word, female students are expected to balance the economics aspect with the environmental aspect, then the tendency will be executing the eco-entrepreneurship or green entrepreneurship.

Table 4. Descriptive Statistics of PGV

\begin{tabular}{llcc}
\hline Indicators & Mean & $\begin{array}{c}\text { Stand. } \\
\text { Deviation }\end{array}$ \\
\hline $\begin{array}{l}\text { Continuously seek the best way to make business } \\
\text { activity prosperous enough for the environment and } \\
\text { the community }\end{array}$ & PGV1 & 3.34 & .553 \\
$\begin{array}{l}\text { Willing to share the value of eco-friendly } \\
\text { environment to those who need the sustainable } \\
\text { environmental information }\end{array}$ & PGV2 & 3.21 & .529 \\
$\begin{array}{l}\text { Willing to educate society or community to preserve } \\
\text { the environment }\end{array}$ & PGV3 & 3.22 & .543 \\
\hline
\end{tabular}

Source: (the output of Smart PLS, 2018)

Based on the information, the results are relevant to the previous study in purchasing behaviour, e.g., (Chen and Chang, 2012), (Rahardjo, 2015), which found the significant impact the green perceived value toward green purchase intention. Other study also proved significant influenced the green perceived value toward green awareness (Syarifudin and Alamsyah, 2017). It signs the growing of awareness or interesting the young people in the sustainability issues. Accordance with (Lotfi et al., 2018), stated that in the emerging green market or green product, entrepreneurs ought to grab the opportunities. Thereby, propensity to sustainable entrepreneurship will ensure the potential to capture the moments. The outcomes of researches can be utilized to foster the knowledge and education in promoting the triple bottom line in the other areas.

\section{DISCUSSION}

Understanding the sustainable entrepreneurship. What is the sustainable entrepreneurship? Accordance with statement of sustainable development which is defined as development that meets the need of the present without compromising the ability of the future generations to meet their own needs, the synergizing the sustainability programs into the business models are progressed to become the sustainable entrepreneurship. The thought was created by Brundtland Commission in 1987. The groundbreaking of concept is to keep the progress of economic development without decreasing natural resources or destroying environment. Thereafter, along thirty two years, statement of sustainability has 
implemented in economic development, specifically in entrepreneurship development areas. The fundamental of thinking the model considers the triple pillars which were coined by (Elkington, 1997). Thereby, existence of sustainable entrepreneurship controls the triple bottom line, so the role of entrepreneurs is to manage the balancing among earth, people, and profit.

Based on Elkington, the sustainable entrepreneurship is constructed by triple domains consist of environmental, social culture, and economic. (Majid and Koe, 2012) develops harmony among four domains such as cultural diversity, social equity, environmental responsibility, economic viability. (Racelis, 2014) introduced the quintuple bottom line such as economic, social, ecological, cultural, and ethical. Although, the domains grow to five aspects, but (Belz and Binder, 2017) back to the three domains. They are done gradually from double to the triple bottom line. In understanding the mechanism for entrepreneurial students learn about sustainable entrepreneurship, the development of domain in sustainable entrepreneurship prefer to shift from double to the triple bottom line. The simplifying of domains will be easy for students when understanding the sustainability business.

Briefly, there are some differences to describe the sustainable entrepreneurship. (Dean and McMullen, 2007) identified the process of finding the economic opportunity which occurred from the market failure. (Cohen and Winn, 2007) emphasized the important means in examining market opportunity before creating products and services. (Patzeld and Shepherd, 2011) showed a form of concern in nature conservation that supports each life and community. (Hockerts and Wustenhagen, 2010) emphasized the essential of seizing economics opportunity through environment, social shifting and sustainability. (Schaltegger and Wagner, 2011) stated creating value through innovative, market-oriented, and personality. The statements concludes that sustainable entrepreneur activities are not only limited to the creation of product and service but also including the commitment and the environment equality. Basically, it needs commitment, consciousness, responsibilities, and integrity to startup the sustainable business. When sustainability determinants are generated in the entrepreneurial students, so it is not easy to understand the sustainability business model. For the reason, the purpose of study emphasizes to identify the interesting of students toward sustainability business. There is a shifting study from the ordinary entrepreneurship model, e.g., (Linan, 2008); (Linan et al., 2013); (Kaijun and Sholihah, 2015); (Gerard and Saleh, 2011); (Turker and Selcuk, 2009); (Ismail et al., 2009) to become a new framework of sustainability, e.g., (Koe et al., 2014), (Koe and Majid, 2014), (Koe et al., 2015), (Koe, 2016), (Majid et al., 2017). Therefore, the role of eco-entrepreneurship or green entrepreneurship model is as a bridge in progressing of the entrepreneurial approach, e.g., (Taylor and Walley, 2004), (Kochen, 2009), (Kirkwood and Walton, 2010), (Abina et al., 2015), (Kartika and Ida, 2017).

Understanding the Intention of Sustainable Entrepreneurship. Despite of having a lot of literatures, but intention is valuable in the behavioural studies. In this field, it is as a cognitive perspective. Because it represents an attempt to understand the formation of new ventures and the underlying structures and processes (Linan et al., 2013). Study of intention has been developed in any areas. TPB relates to the human behaviour, therefore, it is used to analyze the relation of determinants toward sustainable entrepreneurial 
intention. The entrepreneurs or nascent entrepreneurs find many challenges in running their business. Moreover, they will confront to problems when the interest to sustainability business models. The study focus to intention when understanding the process of the new venture formation, specifically their perception in the sustainability issues. For predicting the intention, determined by entrepreneurship education, perceived role models, entrepreneurial support, and green value.

Intention in sustainable entrepreneurship is as desire to practice of starting new business that are profitable and based on goods and services that respect to the environmental benefit and preserve the social culture or local wisdom in the surroundings of entrepreneurs. It reflects the indication of how hard people willing to try the business models in line with sustainability. TPB explains that the human behaviour is as a result from their intention. Thus, intention is as predictor for human behaviour. Based on theory, the intention of sustainable entrepreneurship determines the students' behaviour toward sustainability. Therefore, in the long-term commitment students will prepare and realize their business model appropriate with the principals of sustainable development. For instance, Table 4 shows the perception of students toward the intention on sustainable entrepreneurship. Items are responded in agree with the strongly agree by students. They illustrate the desire to start new business with respecting to environmental benefit and preserve social culture (local wisdom) in Indonesia.

Theoretical Implementation. The first purpose is to determine the dominant factor of the students' intention in the sustainable entrepreneurship. The results show as follows: Firstly, Perceived role models are estimated to have insignificant relation to the sustainable entrepreneurial intention for female students. Who are the role models? According to (Nauta and Kokaly, 2000), define: "role models are people, who either by doing something or by being admirable to you in one or more ways, have had an impact on the academic and career decisions you are making in your life. Role models may be people you know personality, or they may be people you simplly know of who have had an impact on you" (Kennedy et al., 2003). In line with definition, existence of role models are needed in processing of new venture formation.

Actually, the result differs with (Karimi et al., 2014) which proved the entrepreneurial role models influence to the entrepreneurial student intentions. In Karimi's study, the existence of role models able to form the attitude, social norms, and perceived controls in female students. In understanding this study, the role models are able to explain the intention. Beside, (Kennedy et al., 2003) concluded that in executing a business, college students need a role model from parents, friends, experts, public figures, or lecturers. Thereby, a role model acts as the inspiration of entrepreneurs. Conceptually, entrepreneurial role models should supports the potential of intentions models for predicting new venture creation. Contrarily, the result shows the family environment, lecture's project or public figure less to inspire to become sustainability entrepreneur.

Why the determinant is not significant to intention? For explaining the result, it is used the study by (Krueger et al., 2000). Entrepreneurial role models only weakly predict the future the sustainable entrepreneurial intention. They are not considered as the factors in influencing the college students' intention. In other word, the existence of role models could not form the attitude and self-efficacy in entrepreneurial students, then they are not 
interest to become a follower to their role model in attitude context. It means existence of family environmental, lecture's project or public figure weakly impact to intention toward sustainability entrepreneurship. Moreover, sustainable entrepreneurship is a new business models for students, then they have not found the inspiring person become sustainable entrepreneurs. The institution could use the social learning theory from Bandura to foster role models performance in guiding the students.

Secondly, along with progressing the entrepreneurial education program in universities and promoting sustainable development for entrepreneurial students, so the result identifies insignificant effect between entrepreneurship education to the sustainable entrepreneurship intention. Basically, the most students get information and knowledge from entrepreneurial learning, but have not got enough support to execute a startup in sustainable entrepreneurship. Education orientation currently supports the entrepreneurship in general and it has not led to sustainable entrepreneurship. Whereas, entrepreneurship education is responsible to enhance the awareness, knowledge, skill, and value to students (McEwen, 2013). Sustainability-based curriculum support the implementation of sustainable entrepreneurship in the entrepreneurial education system. Basically, the institution gives information linkage to sustainable entrepreneurship, but in practice still emphasizes how to create awareness as entrepreneurs. Students tend to have less self-efficacy to finalize a project to be a startup, so this condition makes sustainable business ideas only a final examination.

Compared with (Kaijun and Sholihah, 2015), in Indonesian case, education support is not significant to entrepreneurial intention. Contrarily, the impact is different to Chinese student. Therefore, the relation pattern of education to sustainable entrepreneurial is similar with (Kaijun and Sholihah, 2015). Moreover, it is equal to prior study of ecoentrepreneurial student intention by (Kartika and Ida, 2017) in the same case in Indonesia or in compliance to (Abina et al., 2015) in Nigeria. The fact show entrepreneurial education only weakly to predict the future of sustainable entrepreneurial intention. In other word, it is not considered as a factor in influencing the intention. Basically, education support form attitude toward sustainable entrepreneurship, but the existence of education is not adequate to form social norm and perceived behavioral control for entrepreneurial students. Therefore, most students are not enough self-efficacy to start the sustainability business. However, institution must foster the role of education support to promote the sustainability business model. In line with (Kaijun and Sholihah, 2015) entrepreneurship education are categorized in three steps, as such (1) skills, (2) development of personal and social skills, (3) skills required for starting a business and financial. When improving the education program, so every stages have to synchronize with sustainable development programs.

Thirdly, Perceived entrepreneurial support insignificantly indicates that most of the students have not got family support or are not sure yet to collaborate with a partner or friends in executing sustainable entrepreneurship. Term of perceived entrepreneurial support is similar to social norm in TPB, family support (Denanyoh et al., 2015), social valuation (Linan and Chen, 2006), ( $\mathrm{Ng}$ and Burke, 2010) or perceived support (Abina et al., 2015). In ordinary entrepreneurship context, the result is different with the prior studies of intention, e.g., (Turker and Selcuk, 2009), (Gelard and Saleh, 2011). Meanwhile, in eco-entrepreneurship approach, it is not equal to prior study by (Kartika 
and Ida, 2017) or (Abina et al., 2015). The result shows that the entrepreneurial support could only predict weakly the future of the sustainable entrepreneurial intention. It means most of students have not considered as the factors in influencing the intention to the sustainability business. Equal to the prior factor, basically, entrepreneurial support form attitude toward sustainable entrepreneurship, but the existence is not adequate to form social norm and perceived behavioral control for entrepreneurial students. Therefore, the impact of entrepreneurial support is not able to form the social pressure on sustainability, and weakly to foster the self-efficacy on sustainable entrepreneurship.

In the double bottom line's concept, it is relevant with previous studies by (Kartika and Ida, 2017) and (Abina et al., 2015), which is proved the significantly impact of perceived support toward eco-entrepreneurial intention. However, in the triple bottom line's concept, the pattern is not proven to intention. In fostering the students, institution could improve to the entrepreneurial support model (ESM) which designed by (Turker and Selcuk, 2009). In ordinary entrepreneurial context, the model is considered predominantly the impact of contextual factors on entrepreneurial intention. The entrepreneurial intention is taken as a function of educational, relational, and structural supports. Continuing the ESM, (Gerard and Saleh, 2011) are able to prove the education support, structural support, and formal networking are significant to entrepreneurial intention in Teheran. The existence of ESM is also proven by (Denanyoh et al., 2015) in Ghana. The next implementation, the ESM has to improve to the sustainable entrepreneurial support model.

Fourth, perceived green value is a significant predictor to sustainable entrepreneurial intention. As millennium generation, youth people aware to the environmental issues. Most of students understand the benefit of green for the people and the earth. Moreover, they have lifestyle to appreciate the value of eco-friendly environment and will collaborate with green community. The result is relevant to (Kirkwood and Walton, 2010), (Kirkwood et al., 2014) which the motivations of ecoentrepreneur is caused by ethics or green value. Accordance with TPB, the perceived of green value will form the attitude toward sustainable entrepreneurship, force the social pressure on sustainability issues, and create self-efficacy to start the eco-friendly business in the future. In the double bottom line's concept, it is equal to (Kartika and Ida, 2017) and (Abina et al., 2015).

Relevant to (Bhatnagar et al., 2013), while women are assumed to be more potential to succeed in their eco-entrepreneurship. Previously, (Braun, 2010) concluded that female entrepreneurs have higher participating to the environmental attitude and commit to the green entrepreneurship program. Corresponding to Millennium Development Goals (MDGs), female is as the priority in gender equality. Thereby, the existence of woman entrepreneurs are expected to contribute either in economic or environmental development. Nevertheless, the role of women ought to contribute to balance among the triple bottom line's goals. Based on logics, female students who tend to have green value have more interest in relevant business on sustainable development. For the reasons, female students are chosen as object to observe the intention, specifically in double bottom line's view.

One approach to introduce sustainable entrepreneurship is through convergent process model (Belz and Binder, 2017). The model introduces six phases as follows: (1) Recognizing social or ecological problem, (2) Recognizing social or ecological 
opportunity, (3) Developing double bottom line solution, (4) Developing triple bottom line solution, (5) Funding and forming the sustainable enterprise, (6) Creating or entering to the sustainable market. The basic concept of sustainable entrepreneurship implementation is on the integration among ecological, social, and economic goals. It is not only focused on the simultaneous goals. The orientation will go gradually from the double bottom line, to focus on economic objective in ecology or economic objective in society. By the processes, entrepreneur's aspirant will prepare to develop the pillars of sustainable entrepreneurship. These stages will be adapted to the readiness and ability of entrepreneur.

Students learn about how to create the value of sustainability business. For instance, accordance to (Evans et al., 2017), the sustainability values are created from triple aspects in the sustainable development. Those values are as follows: (1) Environmental value forms e.g., renewable resource, low emission, low waste, biodiversity, pollution prevention (air, water, land). (2) Social value forms e.g., equality and diversity, wellbeing, community development, secure livelihood, labor standard, health and safety. (3) Economic value forms e.g., profit, return on investment, financial resilience, long-term viability, business stability. Through the knowledge, students understand the process of creating value, then someday they will be desire to drive their business through sustainability values.

Practical Implementation. Next purpose is to design the mechanism of implementation of triple bottom line in the development of entrepreneurial education. Institution should review how far the entrepreneurial education introduces the principles of sustainability to students and ensure when it is starting to incubate the new ventures in the ecoentrepreneurship or sustainable entrepreneurship practices. Referring to (Dean and McMullen, 2007), (Cohen and Winn, 2007), (Pacheco et al., 2010) or (Patzeld and Shepherd, 2011), there are some similarities contents in the definition of sustainable entrepreneurship. The statement is the process of discovering, evaluating, and exploiting economic opportunities. It means the development of the sustainability business model requires the processes. Thus, in the process to discover, evaluate, and exploit the economic opportunities, students or nascent entrepreneurs need supporting from institution. Thereby, education system is strongly needed to contribute to sustainable development. For instance, support could be in the form of knowledge, coaching, information, training or financial support, so that students are able to arrange their ideas in line with double bottom line. Then, they improve to triple bottom line.

Accordance with the theory of planned behaviour, if education institution seriously commits to sustainable development, the learning model will push sustainability knowledge to students. Thereby, it will impact to the personal valuation on sustainability, social pressure on sustainability, and self-efficacy on sustainable entrepreneurship. Generally, the practical implementations for institution are as follows: (1) Through social learning theory from Bandura, institution ought to foster the insider stakeholders in providing learning, motivating students, and become be as inspiration and help individuals define their self-concept. (2) Collaborating between entrepreneurial education program and external stakeholders to engage in sustainable entrepreneurial support model (SESM). Stakeholders' engagement is potentially to encourage students in sustainability or green business. (3) Collaborating alumnus to overcome the funding problems through the 
sustainability crowd funding, overcome the challenges, and serve to capture the opportunities in green market for new ventures. (4) Synergizing between internal regulation and sustainable development, specifically in the sustainable entrepreneurial development. The synchronizing goals are done among center of entrepreneurial study, research roadmap, and strategic planning in education system. Through the collaboration, institution will actualize the purpose of integrity, professionalism, and entrepreneurship based on sustainability issues as a strategic planning in the future. (5) Collaborating with corporate social responsibility to incubate the new venture based on eco nor sustainable entrepreneurship. The collaborations are focused on technology development, recognizing market failure, managing sustainability innovation and risk taking. (6) Involving NGO's e.g., Wahana Lingkungan Hidup to critically give aspiration about environmental and social culture preservation to students. It is a moment to campaign the benefit of ecofriendly business and create the insight for students.

\section{CONCLUSION}

Based on the observation on entrepreneurial female students, it is found the perceived green value has a significantly positive impact on the sustainable entrepreneurial intention, while the other variables are not significant. The results prove understanding of the positive perception about green value among female students and intention to the sustainable entrepreneurship. Along with emerging green market, ecoentrepreneurs or sustainable entrepreneurs ought to grab the opportunities. Basically, most of students have knowledge and experience in entrepreneurship. They have sense of the thinking of the double bottom line as business foundation. Nonetheless, it will be relatively difficult to implement the triple bottom line in startup process. The trend model has attracted college students as the potential way to arrange sustainability between economy and ecology or economy and society. The entrepreneurial education system ought to organize the knowledge about how to create innovation and to take the risk in running the green business. If education institution commits to sustainable development, it will consider sustainability for future generations. Therefore, students will get sufficient knowledge of each process in TBL implementation.

As a recommendation, it is necessary for entrepreneurial universities in Indonesia to appreciate the sustainable entrepreneurship. The education institutions can contributes to the government and world program to balance the goals of ecological, social, and economic. Understanding their perceptions is an important stage when it is designed to the mechanism of the TBL implementation in the high education level, specifically in the development of entrepreneurial education. There are some limitations of the study. For instance, the determinants include four independent variables, some other factors may have been overlooked. This study is not considered the mediating variable. Furthermore, the avenue for future research should include the sustainability attitude as mediating variable for sustainable entrepreneurial intention. 
Acknowledgements. We would like to thank the DPPM of Tarumanagara University that supports the program. Lastly, we appreciate the lecturer assistants of the Financial Management Laboratory who were involved in the research collaboration.

\section{REFERENCES}

Abina, M.B., Oyerin, I.W., and Onikosi-Alliyu, S.O. (2015). Determinants of eco entrepreneurial intention among students: A case study of university students in Ilorin and Malete, Ethiopian Journal of Environmental Studies and Management, 8 (1), 107112. DOI:_http://dx.doi.org/10.4314/ejesm.v8i1.10.

Alhaddi, H. (2015). Triple bottom line and sustainability: a literature review, Business and Management Studies, vol. 1, No. 2, September, 1-5.

Ajzen, I. (1991). The Theory of Planned Behavior, Organizational Behavior and Human Decision Processes, 50, 179-211.

Astuti, R.D. and Martdianty, F. (2012). Students' entrepreneurial intentions by using theory of planned behavior, The case in Indonesia, The South East Asian Journal of Management, October, vol. 6 No. 2, 100-112.

Braun, P. (2010). Going green: women entrepreneurs and the environment, International Journal of Gender and Entrepreneurship, vol. 2 No. 3, 245-259. DOI: $10.1108 / 17566261011079233$.

Bell, J. and Stellingwerf, J.J. (2012). Sustainable entrepreneurship: the motivations and challenges of sustainable entrepreneurs in the renewwable energy industry, thesis, Jankoping International Business School.

Belz, F.M., and Binder, J.K. (2017). Sustainable entrepreneurship: a convergent process model, Journal Businesss Strategy and The Environment, 26, 1-17. DOI: 10.1002/bse.1887.

Bhatnagar, A., Patil Vidyapeeth, D.Y., Bharwaj, B.R. and Gandhi, S. (2013). Women ecopreneurship-a case study from emerging country, Greener Journal of Business and management Studies, vol. 3(2), 091-098, January, 91-98.

Binder, J.K., and Belz, F-Martin. (2013). Sustainable entrepreneurship: what it is, Research Report, Technische Universität München, 1-44.

Bird, B. (1988). Implementing entrepreneurial ideas: The case for intention. Academy of Management Review, 13 (3), 442-453.

Chen, Y. and Chang, C. (2012). Enhance green purchase intention: the role of green perpective value, green percived risk, and green trust, Management Decision, vol. 50 No. 3. DOI: $10.1108 / 00251741211216250$.

Choi, D., and Gray, E. (2008). The venture development processes of "sustainable" entrepreneurs. Management Research News, 8 (31), 558-569.

Cohen, B. and Winn, M.I., (2007). Market imperfections, opportunity and sustainable entrepreneurship, Journal of Business Venturing, 22, 29-49. DOI: 10.1016/j.jbusvent.2004.12.001

Dean, Thomas, J., and McMullen, Jeffery S. (2007). Toward a theory of sustainable entrepreneurship: Reducing environmental degradation through entrepreneurial 
action, Journal of Business Venturing, 22, 50-57. DOI: 10.1016/j.jbusvent.2005.09.003

Denanyoh, R., Adjei, K. and Nyemekye, G.E. (2015). Factors that impact on entrepreneurial intention of tertiary students in Ghana, International Journal of Business and Social Research Volume 05, Issue 03. 19-29.

Elkington, J. (1999). Cannibals with Forks: The Triple Bottom Line of $21^{\text {st }}$ Century Business, Captone: Oxford UK.

Evans, S., Vladimirova, D., Holgado, M., Fossen, K.V., Yang, M., Silva, E.A., and Barlow, C.Y. (2017). Business model innovation for sustainability:towards a unified perspective for creation of sustainable business models, Business Strategy and the Environment, 1-12. DOI: 10.1002/bse.1939

Fong, N., Wolfgramm, R., and Shepherd, D. (2014). Entrepreneurship, start-up and small business, ANZAM, 1-9.

Gerard, P., and Saleh, K.E. (2011). Impact of same contextual factors on entrepreneurial intention of university students., African Journal of Business Management, vol. 5 (26), October, 10707-10717. DOI: 10.5897/AJBM10.891

Harris, M.L. and Gibson, S.G. (2008). Examining the entrepreneurial attitudes of US business student, Education and Trainning, 50 (7), 568-581. DOI: 10.1108/00400910810909036.

Henseler, Jörg., Ringle, Christian M. and Sarstedt, Marko (2012). Using Partial Least Squares Path Modeling in International Advertising Research: Basic Concepts and Recent Issues. in Okzaki, S, Eds. Handbook of Partial Least Squares: Concepts, Methods and Applications in Marketing and Related Fields. Berlin: Springer, 252276.

Hockerts, K., and Wüstenhagen, R. (2010). Greening goliaths versus emerging davids: theorizing about the role of incumbents and new entrants insustainable entrepreneurship, Journal of Business Venturing, 25, 481-492. DOI:10.1016/j.jbusvent.2009.07.005

Höck, Michael and Ringle, Christian M. (2006). Strategic Networks in the Software Industry: An Empirical Analysis of the Value Continuum. IFSAM VIII ${ }^{\text {th }}$ World Congress, Berlin 2006. Retrieved 02/22/2009, http://www.iblunihh.de/IFSAM06.pdf.

Ismail, M., Khalid, S. A., and Othman. (2009). Entrepreneurial intention among Malaysian undergraduates, International Journal of Business and Management, vol. 4, No. 10, October, 54-60.

Kaijun, Y. and Sholihah, P.I. (2015). A comparative study of the Indonesia and chinese educative system concerning the diminant incentive to entrepreneurial spirit (desire for a new venturing) of business school students, Journal of Innovation and Entrepreneurship, 1-16. DOI: 10.1186/s13731-014-0014-0.

Karimi, S., Biemans Harm J.A. Lans, T., Chizari M. and Mulder M. (2014). Effects of role models and gender on students' entrepreneurial intentions", European Journal of Training and Development, vol. 38, 8, 1-34. DOI: 10.1108/EJTD-03-2013-0036

Kartika Nuringsih and Ida Puspitowati (2017). Determinants of eco entrepreneurial intention among students: study in the entrepreneurial education practices, Advanced Science Letters, 5, No. 23. August, 7281-7284. 
Kennedy, J., Drennan, J., Renfrow, P. and Watson, B., (2003). The influence of role models on students' entrepreurial intentions, Queensland Review, 10 (1). 37-52.

Kirkwood, J., and Walton, S. (2010). What motivates ecopreneurs to start business?, International Journal of Entreprenurial Behavior and Research, vol. 16 No. 3, 204228. DOI: $10.1108 / 13552551011042799$.

Kirkwood, J., Dwyer. K., and Walton, S. (2014). An ecopreneurs road resiliance after earthquake, $27^{\text {th }}$ annual SEAANZ Conference Procedings, 16-18 July, Sidney.

Koe, Wei-Loon, Omar, Roaimah, and Majid, Izaidin Abdul. (2014). Factors Associated with Propensity for Sustainable Entrepreneurship, Procedia-Social and Behavioral Sciences, vol. 130, 65-74. DOI: 10.1016/j.sbspro.2014.04.009.

Koe, Wei-Loon, Omar, Roaimah, and Sa'ari, Juan Rizal. (2015). Factors Influencing Propensity to Sustainable Entrepreneurship of SMEs in Malaysia, Procedia-Social and Behavioral Sciences, vol. 172, 570-577. DOI: 10.1016/j.sbspro.2015.01.404.

Koe, Wei-Loon., and Majid, Izaidin Abdul. (2014). Socio-Cultural Factors and Intention towards Sustainable Entrepreneurship, Eurasian Journal of Business and Economics 2014, 7 (13), 145-156.

Koe, Wei-Loon (2016). The relationship between individual entrepreneurial orientation (IEO) and entrepreneurial intention, Journal of Global Entrepreneurship Research, 6, 13, 1-11. DOI 10.1186/s40497-016-0057-8

Kotchen, M.J. (2009). Advances in the study of entrepreneurship innovation and economic growth, Emerald Group Publishing Limeted.

Krueger, N.F., Reilly, M.D. and Carsrud, A.L. (2000). Competing models of entrepreneurial intentions, Journal of Business Venturing, 15 (5/6), 411-432.

Kuckertz., A. and Wagner., M. (2010). The influence of sustainability orientation on entrepreneurial intentions Investigating the role of business experience, Journal of Business Venturing, 25, 524-539. DOI:10.1016/j.jbusvent.2009.09.001.

Lee, S.H. and Wong, P.K. (2004). An explanatory study of technopreneurial intention: a career anchor perspective, Jurnal of Business Venturing, 19 (1), 7-28. DOI: 10.1016/so883-9026/(02)00112-x.

Linan, F., and Chen, Y. (2006). Testing the entrepreneurial intention model on two country sample, University of Sevil.

Linan, F. (2008). Skill and value perception: How do they effect entrepreneurial intention, International Entrepreneurial Management Journal, 4, 257-272. DOI: 10.1007/s11365-008-0093-0.

Linan, F., Nabi, G., and Krueger, N. (2013). British and spanish entrepreneurial intentions: a comparati ve study, Revista de Economía Mundial 33, 73-103.

Lotfi, M., Yousefi, A. and Jafari., S. (2018). The effect of emerging green market on green entrepreneurship and sustainable development in knowledge-based companies, Sustainability, 10, 1-18. DOI: 10.3390/su10072308.

Majid, Izaidin Abdul, and Koe, Wei-Loon. (2012). Sustainable entrepreneurship (SE): a revised model based on triple bottom line (TBL). International Journal of Academic Research in Business and Social Sciences, June, vol. 2 No. 6, 293-310.

Majid, Izaidin Abdul, Latif., A., and Koe, Wei-Loon. (2017). SMEs' intention towards sustainable entrepreneurship, European Journal of Multidisciplinary Studies, vol. 2, issue 3, 24-32. 
Maresch., D., Harms, R., Kailer, N., and Wimmer-Wurn, B. (2015). Impact of entrepreneurship education on the entrepreneurial intention of student science and engineering versus business studies university program., Technological Forecasting and Social Change. Http;//dx.doi.org./10.1016/j.techfore.2015.11.006.

McEwen, T. (2013). Ecopreneurship as a solution to environmental problems: implications for college level entrepreneurship education, International Journal of Academic Research in Business and Social Sciences, May, vol. 3 No. 5., 264-288.

$\mathrm{Ng}$, Eddy, S.W., and Burke, Ronald J. (2010). Predictor of business students' attitudes toward sustainable business practices, Journal of Business Ethic, 95, 603-615. DOI: 10.1007/s10551-010-0442-0.

Nishimura, J.S., and Tristan, O.M. (2011). Using the theory of planned behavior to predict nascent entreprenurship, Academy Revista Latinoamericaa de Administracion, 46, 5571

Pacheco, D.F., Dean, T.J., and Payne, D.S. (2010). Escaping the green prison: Entrepreneurshipand the creation of opportunities for sustainable development, Journal of Business Venturing, 25 (5), 464-480.

Patzelt, H. and Shepherd, D.A. (2011). Recognizing opportunities for sustainable development, Entrepreneurship Theory and Practice, July, 631-652. DOI: 10.1111/j.1540-6520.2010.00386.x.

Racelis, A.D. (2014). Sustainable Entrepreneurship in Asia: A Proposed Theoretical Framework Based on Literature Review, Journal of Management for Global Sustainability, vol. 2, issue 1, 49-72.

Rahardjo, F.A. (2015). The role of green perceived value, green percived risk, and Green Trust towards Green Purchase Intention of Inverter Air Conditioner in Surabaya, iBuss Management, vol. 3, No. 2, 252-260.

Remeikiene, R., Startiene, G., and Dumciuviene, D. (2013). Explaining entrepreneurial intention of university students: the role of entrepreneurial education, Management, Knowledge, and Learning International Conference, 299-307.

Sahinidis, A. G., Giovanis, A. N., and Sdrolias, L. (2012). The role of gender on entrepreneurial intention among students: an empirical test of the theory of planned behavior in a Greek university, International Journal on Integrated Information Management, vol. 1, 117-130. DOI: 10.15556/IJIIM.01.02.005.

Schaltegger., S. and Wagner., M. (2011). Sustainable Entrepreneurship and Sustainability Innovation: Categories and Interactions, Business Strategy and the Environment, 20, 222-237. DOI: 10.1002/bse.682.

Schaper, M. (2002). The essence of ecopreneurship. Greener Management International, 38 (Summer), 26-30.

Schlange, L. E. (2009). Stockholder perception in sustainable entrepreneurship: the role of managerial and organizational cognition., First World Symposium on Sustainable Entrepreneurship. Devonshire Hall University of Leeds UK, July 6-17: 1-24

Shepherd, D. and Patzelt, H. (2010). The new field of sustainable entrepreneurship: studying entrepreneurial action linking "what is to be sustained" with "what is to be developed". Entrepreneurship Theory and Practice, vol. 35, issue 1, 137-163. 
Singh, Mitrabinda. (2009). Greening tommorow's markets: an advantage or a way to hijack the sustainability, agenda, in Professor Mohammed Quddus (ed), Curtin International Business Conference 10-12 December, Curtin, Sarawak, Malaysia, 1-8.

Strange, T. and A. Bayley. (2008). Sustainable Development Lingking Economy, Society, Environment.

http://www.sjalfbaerni.is/media/frodleikur/OECD-skyrsla.pdf.

Syarifuddin., D. and Alamsyah., D.P. (2017). Green purchase value for environmental friendly products: green awareness improvement, Jurnal Ekonomi Pembangunan, 18, (2), 245-255. DOI: $10.23917 /$ jep.v18i2.5145.

Taylor, D.W., and Walley, E.E (Liz). (2004). The green entrepreneur: opportunist, moverick or visionary?, International Journal Entreprenurship and Small Business, vol. 1 Nos. $1 / 2,56-69$.

Tilley, F., and Young, W. (2009). Sustainability entrepreneur: could they be the true wealth generators of the future?, Greener Management International, issue 55, 79-92.

Turker, D., and Selcuk, S. S. (2008). Which factors affect entrepreneurial intention of university students? Journal of European Industrial training, vol. 33, No. 2,142-159. DOI: 10.1108/03090590910939049.

Zikmund, W.B., and Babin, B,J. (2010). Essential of Marketing Research, $4^{\text {th }}$ Edition, Mason, $\mathrm{OH}$. 